\title{
PENGARUH RETURN ON ASSET (ROA), PRICE EARING RATIO (PER), EARNING PER SHARE (EPS), DEBT TO EQUIY RATIO (DER) DAN PRICE TO BOOK VALUE (PBV) TERHADAP HARGA SAHAM PADA PT. BANK NEGARA INDONESIA (PERSERO) TBK, PERIODE 2005-2016
}

\author{
Hani Fitria Rahmani \\ Fakultas Ekonomi Universitas Nasional Pasim \\ Jl. Dakota No.8a Sukaraja Bandung \\ Email: hanifr18@gmail.com
}

\begin{abstract}
ABSTRAK
Pasar modal merupakan sarana perusahaan untuk meningkatkan kebutuhan dana jangka panjang dengan menjual saham atau mengeluarkan obligasi. Krisis keuangan global tahun 2008 mengakibatkan kondisi pasar keuangan menjadi terpuruk, termasuk pasar modal di Indonesia. Return On Asset (ROA), Price Earing Ratio (PER), Earning Per Share (EPS), Debt To Equiy Ratio (DER) dan Price To Book Value (PBV) merupakan suatu analisis laporan keuangan untuk mengetahui nilai kinerja keuangan suatu perusahaan. Tujuan penelitian ini adalah untuk mengetahui dan menganalisis bagaimana pengaruh variabel Return On Asset (ROA), Price Earing Ratio (PER), Earning Per Share (EPS), Debt To Equiy Ratio (DER) dan Price To Book Value (PBV) terhadap nilai harga saham pada PT. Bank Negara Indonesia (Persero) Tbk, baik secara simultan maupun parsial. Hasil penelitian secara parsial ROA, PER dan DER tidak memiliki pengaruh signifikan terhadap harga saham, sedangkan EPS dan PBV memiliki pengaruh signifikan terhadap harga saham. Adapun besarnya pengaruh secara simultan Return On Asset (ROA), Price Earning Ratio (PER), Earning Per Share (EPS), Debt to Equity Ratio (DER) dan Price to Book Value (PBV) terhadap harga saham sebesar $97,7 \%$.
\end{abstract}

Kata Kunci : Return On Asset (ROA), Price Earing Ratio (PER), Earning Per Share (EPS), Debt To Equiy Ratio (DER) dan Price To Book Value (PBV), harga saham.

\section{PENDAHULUAN}

Indonesia merupakan salah satu

Negara yang ikut berperan serta dalam perdagangan internasional. Seperti halnya pasar pada umumnya, pasar modal merupakan tempat bertemunya antara pembeli dan penjual dengan resiko untung dan rugi. Pasar modal merupakan sarana perusahaan untuk meningkatkan kebutuhan dana jangka panjang dengan menjual saham atau mengeluarkan obligasi. Menurut Darmadji dan Fakhruddin (2011:1) "Pasar modal merupakan pasar untuk berbagai instrument keuangan jangka panjang yang bisa diperjualbelikan, baik dalam bentuk utang ataupun modal sendiri”. 
Krisis keuangan global tahun 2008 mengakibatkan kondisi pasar keuangan menjadi terpuruk, termasuk pasar modal di Indonesia. Rontoknya indeks bursa di hampir seluruh dunia pada Oktober 2008 lalu turut menghempaskan Indeks Bursa Harga Saham Gabungan (IHSG) hingga level terendah, yang mengakibatkan BEI terpaksa disuspend sebab mengalami penurunan signifikan. Terjadinya krisis keuangan global tersebut berlaku bagi PT. Bank Negara Indonesia Tbk, dimana Bank merupakan jantung perekonomian suatu negara.

Harga saham merupakan acuan para investor dalam mengambil keputusan investasi. Harga saham sering kali berubah-ubah menyesuaikan dengan tingkat penawaraan dan permintaan. Permintaan terhadap saham dipengaruhi oleh berbagai informasi yang dimiliki atau diketahui oleh para investor mengenai perusahaan emiten, salah satunya adalah informasi keuangan perusahaan yang tercermin dari laporan keuangan perusahaan.

Laporan Keuangan mencerminkan wujud tanggungjawab manajemen perusahaan kepada pihak intern maupun ekstern mengenai kinerja perusahaan selama satu periode. Informasi yang tersaji dalam laporan keuangan belum memberikan informasi yang optimal sebelum dilakukan analisis lanjutan, salah satunya dalam bentuk analisis rasio keuangan. Rasio keuangan merupakan kegiatan membandingkan angka-angka yang ada dalam laporan keuangan dengan cara membagi satu angka dengan angka lainnya Kasmir (2012:104).

Alat bantu rasio keuangan yang dilakukan dalam penelitian ini adalah Return On Asset (ROA), Price Earning Ratio (PER), Earning Per Share (EPS), Debt to Equity Ratio (DER), dan Price to Book Value (PBV). Rasio keuangan diukur untuk menetukan pengaruhnya terhadap harga saham perusahaan.

PT. Bank Negara Indonesia merupakan salah satu perusahaan perbankan dengan asset terbesar yaitu sebesar Rp. 603 Triliun menurut data statistik perbankan OJK per tahun 2016. Penulis memfokuskan penelitian pada perusahaan perbankan yaitu PT. Bank Negara Indonesia . Adapun data dinamika pergerakan harga saham dan rasio-rasio keuangan perbankan yang tercatat di Bank Indonesia adalah sebagai berikut:

\section{Tabel 1. Harga Saham dan Rasio}

Keuangan PT. BNI 


\begin{tabular}{|c|c|c|c|c|c|c|}
\hline Tahun & $\begin{array}{c}\text { Nilai } \\
\text { Harga } \\
\text { Saham }\end{array}$ & $\begin{array}{c}\text { Nilai } \\
\text { ROA }\end{array}$ & $\begin{array}{c}\text { Nilai } \\
\text { PER }\end{array}$ & $\begin{array}{c}\text { Nilai } \\
\text { EPS }\end{array}$ & $\begin{array}{c}\text { Nilai } \\
\text { DER }\end{array}$ & $\begin{array}{c}\text { Nilai } \\
\text { PBV }\end{array}$ \\
\hline 2005 & 1280 & 1.60 & 12.08 & 106 & 11.42 & 1.44 \\
\hline 2006 & 1870 & 1.90 & 12.90 & 145 & 10.45 & 1.68 \\
\hline 2007 & 1970 & 0.90 & 30.78 & 64 & 9.65 & 1.75 \\
\hline 2008 & 680 & 1.10 & 8.50 & 80 & 12.07 & 0.67 \\
\hline 2009 & 1980 & 1.70 & 12.15 & 163 & 30.62 & 1.59 \\
\hline 2010 & 3875 & 2.50 & 14.57 & 266 & 6.50 & 2.18 \\
\hline 2011 & 3800 & 2.90 & 12.18 & 312 & 6.90 & 1.89 \\
\hline 2012 & 3700 & 2.90 & 9.79 & 378 & 6.66 & 1.58 \\
\hline 2013 & 3950 & 3.40 & 8.13 & 486 & 6.91 & 1.53 \\
\hline 2014 & 6100 & 3.50 & 10.55 & 578 & 5.15 & 1.86 \\
\hline 2015 & 4990 & 2.60 & 10.25 & 487 & 5.26 & 1.19 \\
\hline 2016 & 5525 & 2.70 & 9.06 & 610 & 5.52 & 1.15 \\
\hline
\end{tabular}

Berdasarkan uraian dan pergerakan dinamika harga saham dan rasio keuangan di atas maka penulis untuk membahas hal ini di dalam suatu penelitian.

Adapun hipotesis penelitian adalah sebagai berikut:

1. Terdapat pengaruh Return On Assets (ROA) terhadap Harga Saham.

2. Terdapat pengaruh Price Earing Ratio (PER) terhadap Harga Saham.

3. Terdapat pengaruh Earning Per Share (EPS) terhadap Harga Saham.

4. Terdapat pengaruh Debt To Equiy Ratio (DER) terhadap Harga Saham.

5. Terdapat pengaruh Price To Book Value (PBV) terhadap Harga Saham.

6. Terdapat pengaruh secara simultan antara Return On Assets (ROA), Price Earing Ratio (PER), Earning Per Share (EPS), Debt To Equiy
Ratio (DER), Price To Book Value

(PBV) terhadap Harga Saham

\section{KAJIAN PUSTAKA}

\subsection{Pengertian Laporan Keuangan}

Pengertian laporan keuangan menurut Pernyataan Standar Akuntansi Keuangan (PSAK) No.1 paragraf 9 tahun 2015 menyatakan bahwa laporan keuangan adalah suatu penyajian terstruktur dari posisi keuangan dan kinerja keuangan suatu entitas. Laporan keuangan merupakan output dari seluruh transaksi yang terjadi selama periode tertentu yang berisikan seluruh informasi keuangan perusahaan dalam periode tertentu. Menurut Sofyan Safri Harahap (2011:70) Laporan keuangan adalah menyediakan informasi yang menyangkut posisi keuangan, kinerja serta perubahan posisi keuangan suatu perusahaan yang bermanfaat bagi sejumlah besar pemakai dalam pengambilan keputusan ekonomi. Menurut Munawir (2014:2) Laporan keuangan pada dasarnya adalah hasil dari proses akuntansi yang dapat diinginkan sebagai alat untuk berkomunikasi antara data keuangan atau aktivitas suatu perusahaan dengan pihak-pihak yang berkepentingan dengan data atau aktivitas perusahaan. 


\subsection{Pengertian Analisis Laporan Keuangan}

Menurut Munawir (2014:35), analisis laporan keuangan adalah analisis laporan keuangan yang terdiri dari penelaahan atau mempelajari daripada hubungan dan tendensi atau kecenderungan (trend) untuk menentukan posisi keuangan dan hasil operasi serta perkembangan perusahaan yang bersangkutan. Kegiatan dalam menganalisis laporan keuangan dapat dilakukan dengan cara menentukan dan mengukur antara pos - pos uang ada dalam satu laporan keuangan dengan beberapa periode atau dalam satu periode. Analisis laporan keuangan dapat digunakan sebagai alat untuk membantu pengambilan keputusan dan analisis ini memakai laporan keuangan sebagai informasi. Para pengambil keputusan membutuhkan informasi yang tepat dan relevan sebelum suatu keputusan diambil, karena analisis ini digunakan sebagai salah satu dasar untuk mengambil keputusan, maka hasil analisis harus disajikan dengan jelas dan dapat dimengerti.

\subsection{Pengertian Return On Asset (ROA)}

Return On Asset (ROA) menurut Sutrisno (2012:222) adalah ukuran kemampuan perusahaan dalam menghasilkan laba dengan semua aktiva yang dimiliki oleh perusahaan. Selain itu, ROA memberikan ukuran yang lebih baik atas profitabilitas perusahaan karena menunjukan efektivitas manajemen dalam menggunakan aktiva untuk memperoleh pendapatan. Rasio ini digunakan untuk mengukur kemampuan manajemen perusahaan dalam memperoleh keuntungan (laba) secara keseluruhan. Menurut Tandelin (2010:378) dalam bukunya Portopolio dan Investasi, Return On Asset (ROA) merupakan ukuran kemampuan perusahaan di dalam menghasilkan keuntungan (Return) bagi perusahaan dengan memanfaatkan aktiva yang dimilikinya. Menurut Sartono (2008:123) "Return on assets (ROA) merupakan rasio untuk menunjukkan kemampuan perusahaan menghasilkan laba dari aktiva yang dipergunakan.”

\subsection{Pengertian Price Earning Ratio (PER)}

Menurut Iman Santoso (2009:230) Price Earnings Ratio (PER) atau rasio harga laba yaitu ratio yang menunjukan perbandingan antara harga saham dengan laba per saham. Sedangkan 
menurut Irham Fahmi (2013:138), pengertian price earning ratio adalah: Perbandingan antara market price pershare (harga pasar per lembar saham) dengan earning pershare (laba perlembar saham) terhadap kenaikan pertumbuhan laba yang diharapkan juga akan mengalami kenaikan. Menurut Brigham dan Houston (2010:150), Price Earning Ratio adalah: Rasio harga per saham terhadap laba per saham menunjukkan jumlah yang rela dibayarkan oleh investor untuk setiap dolar laba yang dilaporkan.

\subsection{Pengertian Earning Per Share (EPS)}

Menurut Kasmir (2012:207). Earning Per Share (EPS) merupakan rasio untuk mengukur keberhasilan manajemen dalam mencapai keuntungan bagi pemegang saham. Menurut Munawir (2014:241) Earning Per Share (EPS) yaitu rasio antara laba dengan lembar saham yang beredar. Menurut Sutrisno menyatakan bahwa "Earning Per Share (EPS) merupakan ukuran kemampuan perusahaan untuk menghasilkan keuntungan per lembar saham yang dimiliki oleh pemilikya." Menurut Eduardus Tandelilin (2010:373) menyatakan komponen penting pertama yang harus diperhatikan dalam analisis perusahaan adalah laba per lembar saham yang dikenal dengan earnings per share.

\subsection{Pengertian Debt to Equity Ratio (DER)}

Debt to Equity Ratio (DER) menurut Kasmir (2012:157) merupakan rasio yang digunakan untuk menilai utang dan ekuitas. Rasio ini dicari dengan cara membandingkan antara seluruh utang, termasuk utang lancar dengan seluruh ekuitas. Bagi bank (kreditor) semakin besar rasio ini akan semakin tidak menguntungkan karena semakin besar resiko yang ditanggung atas kegagalan yang mungkin terjadi di perusahaan.

\subsection{Pengertian Price to Book Value (PBV)}

Price to Book Value (PBV) Menurut Darmadji dan Fakhruddin (2011:157) PBV adalah : "Menggambarkan seberapa besar menghargai nilai buku saham suatu perusahaan. semakin tinggi rasio ini berarti pasar percaya akan prospek perusahaan tersebut." Price to Book Value (PBV) menurut Wild dan Subramanyam (2007:223), "Nilai buku per lembar saham (Book value per 
share) adalah angka per lembar saham yang berasal dari likuidasi perusahaan pada jumlah yang dilaporkan dalam neraca. Nilai buku (Book value) merupakan istilah konvensional yang mengacu pada nilai aktiva bersih yaitu, total aktiva dikurangi dengan klaim terhadapnya. Nilai buku saham biasa (Book value of common stock) sama dengan total aktiva dikurangi kewajiban dan klaim efek diprioritaskan (seperti saham preferen) pada jumlah yang dilaporkan dalam (neraca namun dapat meliputi pula klaim efek yang diprioritaskan yang tidak tercatat)".

\subsection{Pengertian Harga Saham}

Saham adalah surat berharga yang menunjukkan kepemilikan perusahaan sehingga pemegang saham memiliki hak klaim atas dividen atau distribusi lain yang dilakukan perusahaan kepada pemegang sahamnya, termasuk hak klaim atas aset perusahaan dengan prioritas setelah hak klaim pemegang surat berharga lain dipenuhi jika terjadi likuiditas. Menurut Jogiyanto (2008:167) "harga saham adalah harga suatu saham yang terjadi di pasar bursa pada saat tertentu yang ditentukan oleh pelaku pasar dan ditentukan oleh permintaan dan penawaran saham yang bersangkutan di pasar modal”. Menurut
Husnan (2007:303), menyebutkan bahwa: "Sekuritas (saham) merupakan secarik kertas yang menunjukkan hak pemodal (yaitu pihak yang memiliki kertas tersebut) untuk memperoleh bagian dari prospek atau kekayaan organisasi yang menerbitkan sekuritas tersebut dan berbagai kondisi yang memungkinkan pemodal tersebut menjalankan haknya”.

\section{METODE PENELITIAN}

Dalam penelitian ini metode yang digunakan adalah deskritif dan asosiatif. Metode deskritif adalah metode yang bersifat memberikan gambaran, memaparkan, menulis dan melaporkan keadaan suatu perusahaan. Metode ini digunakan untuk mencari kesimpulan secara umum (Bambang S. Soedibjo 2013:7).

Metode asosiatif dapat dikatakan kelanjutan dari metode deskritif, yaitu kita hanya menghimpun, menyajikan secara cermat dan teliti melalui metode asosiatif dapat dibangun suatu teori yang menjelaskan, meramalkan atau mengendalikan sesuatu gejala tertentu (Bambang S. Soedibjo, 2013:8). Metode asosiatif dapat dikatakan sebagai metode korelasional. Metode ini digunakan untuk melihat 2 variabel atau lebih 
Variabel penelitian yang akan digunakan penulis untuk mengukur nilai dari variabel terbagi menjadi 2 yaitu vaiabel independen dan variabel dependen adalah sebagai berikut :

1. Variabel Independen adalah ROA $\left(\mathrm{X}_{1}\right)$

2. Variabel Independen adalah PER $\left(\mathrm{X}_{2}\right)$

3. Variabel Independen adalah EPS $\left(\mathrm{X}_{3}\right)$

4. Variabel Independen adalah DER $\left(\mathrm{X}_{4}\right)$

5. Variabel Independen adalah PBV $\left(\mathrm{X}_{5}\right)$

6. Variabel Dependen adalah Harga Saham (Y)

Tabel 1. Variabel Penelitian

\begin{tabular}{|c|c|c|c|}
\hline $\begin{array}{c}\text { Varia } \\
\text { bel }\end{array}$ & Definisi & Indikator & $\begin{array}{l}\text { Skala } \\
\text { Penguk } \\
\text { uran }\end{array}$ \\
\hline ROA & $\begin{array}{lr}\text { Return On } & \text { Asset } \\
\text { (ROA) } & \text { adalah } \\
\text { ukuran kemampuan } \\
\text { perusahaan dalam } \\
\text { menghasilkan laba } \\
\text { dengan semua } \\
\text { aktiva yang dimiliki } \\
\text { oleh perusahaan. } \\
\text { Sutrisno (2012:222) }\end{array}$ & $\begin{array}{l}\text { ROA } \\
= \\
\underline{\text { EBIT } \times 100 \%} \\
\text { Total Aktiva }\end{array}$ & Rasio \\
\hline \multirow[t]{2}{*}{ PER } & \begin{tabular}{ll}
\multicolumn{3}{c}{ Price Earning Ratio } \\
(PER) atau rasio \\
harga laba yaitu
\end{tabular} & $\begin{array}{l}\text { PER } \\
= \\
\text { Harga Pasar }\end{array}$ & \multirow[t]{2}{*}{ Rasio } \\
\hline & $\begin{array}{l}\text { ratio yang } \\
\text { menunjukan } \\
\text { perbandingan antara } \\
\text { harga saham dengan } \\
\text { laba per saham. }\end{array}$ & $\begin{array}{l}\text { Saham } \\
\text { Harga per Lembar } \\
\text { Saham/ } \\
\text { Earning Per } \\
\text { Share (EPS) }\end{array}$ & \\
\hline
\end{tabular}

\begin{tabular}{|c|c|c|c|}
\hline $\begin{array}{c}\text { Varia } \\
\text { bel }\end{array}$ & Definisi & Indikator & $\begin{array}{l}\text { Skala } \\
\text { Penguk } \\
\text { uran }\end{array}$ \\
\hline & $\begin{array}{l}\text { Iman Santoso } \\
(2009: 230)\end{array}$ & & \\
\hline EPS & $\begin{array}{l}\text { Earning } \text { Per } \\
\text { (EPS) merupakan } \\
\text { rasio untuk } \\
\text { mengukur } \\
\text { keberhasilan } \\
\text { manajemen dalam } \\
\text { mencapai } \\
\text { keuntungan bagi } \\
\text { pemegang saham } \\
\text { Kasmir (2012:207). }\end{array}$ & $\begin{array}{l}\text { EPS } \\
= \\
\text { Laba saham biasa } \\
\text { Saham biasa yang } \\
\text { beredar }\end{array}$ & Rasio \\
\hline DER & 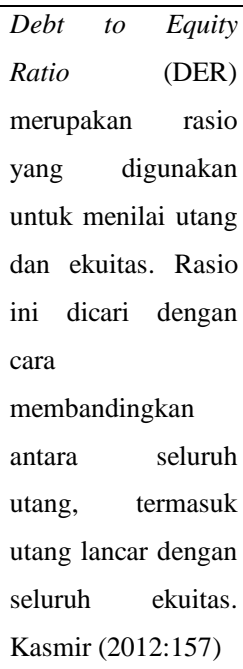 & $\begin{array}{l}\text { DER } \\
= \\
\frac{\text { Total Hutang }}{(\text { Debt })} \\
\text { Ekuitas (Equity) }\end{array}$ & Rasio \\
\hline PBV & $\begin{array}{l}\text { Price to Book Value } \\
(P B V) \text { adalah } \\
\text { "Menggambarkan } \\
\text { seberapa besar } \\
\text { menghargai nilai } \\
\text { buku saham suatu } \\
\text { perusahaan", } \\
\text { Menurut Darmadji } \\
\text { dan Fakhruddin } \\
\text { (2011:157) }\end{array}$ & $\begin{array}{l}\text { PBV } \\
= \\
\text { Harga pasar per } \\
\text { lembar saham } \\
\text { Nilai buku per } \\
\text { saham }\end{array}$ & Rasio \\
\hline $\begin{array}{c}\text { Harga } \\
\text { Saha } \\
\text { m }\end{array}$ & $\begin{array}{l}\text { Harga Saham } \\
\text { adalah harga suatu } \\
\text { saham yang terjadi } \\
\text { di pasar bursa pada }\end{array}$ & $\begin{array}{l}\text { Harga Penutupan } \\
\text { Saham }\end{array}$ & Rasio \\
\hline
\end{tabular}




\begin{tabular}{|c|c|c|c|}
\hline $\begin{array}{c}\text { Varia } \\
\text { bel }\end{array}$ & Definisi & Indikator & $\begin{array}{l}\text { Skala } \\
\text { Penguk } \\
\text { uran }\end{array}$ \\
\hline & $\begin{array}{lr}\text { saat tertentu yang } \\
\text { ditentukan } & \text { oleh } \\
\text { pelaku pasar } & \text { dan } \\
\text { ditentukan } & \text { oleh } \\
\text { permintaan } & \text { dan } \\
\text { penawaran } & \text { saham } \\
\text { yang bersangkutan } \\
\text { di pasar } & \text { modal. } \\
\text { Jogiyanto } & \\
\text { (2008:167) } & \end{array}$ & & \\
\hline
\end{tabular}

Dalam penelitian ini ada lima variabel independen yang digunakan yaitu ROA sebagai $\mathrm{X}_{1}$, PER sebagai $\mathrm{X}_{2}$, EPS sebagai $X_{3}$, DER sebagai $X_{4}$ dan PBV sebagai $X_{5}$ yang menjadi variabel dependen dalam penelitian ini adalah Harga Saham sebagai Y. Data yang digunakan dalam penelitian ini adalah laporan keuangan tahunan yang di keluarkan oleh PT. Bank Negara Indonesia (Persero) Tbk. tahun 20052016.

Metode analisis data menggunakan analisis regresi linier berganda untuk meramalkan variabel dependen berdasarkan variabel independen. Analisis regresi berbentuk linier atau non linier Dari sisi variabel independen dapat berbentuk linier sederhana (dua variabel) atau multivariable (lebih dari satu variabel independen) (Bambang S Soedibjo, 2013 : 205) dan sedangkan untuk hasil tingkat signifikan pengaruh ROA, PER, EPS, DER dan PBV terhadap Harga Saham secara parsial dan menarik kesimpulan diterima atau ditolaknya pengujian, maka penulis menggunakan uji t. Serta untuk mengetahui tingkat signifikan pengaruh ROA, PER, EPS, DER dan PBV terhadap Harga Saham secara simultan mengunakan uji $\mathrm{F}$ dan menarik kesimpulan diterima atau ditolaknya pengujian

\section{HASIL PENELITIAN}

Objek dalam penelitian ini adalah Return On Asset (ROA), Price Earing Ratio (PER), Earning Per Share (EPS), Debt To Equiy Ratio (DER) dan Price To Book Value (PBV) terhadap nilai harga saham pada PT. Bank Negara Indonesia (Persero) Tbk, Periode 20052016.

\subsection{Hasil Uji Asumsi Klasik}

\section{Uji Normalitas}

Pengujian normalitas data dilakukan dengan variabel Return on Asset (ROA), Price Earning Ratio (PER), Earning Per Share (EPS), Debt to Equity Ratio (DER), Price to Book Value (PBV), Harga Saham Pada PT.Bank Negara Indonesia (Persero) Tbk. Periode 2005-2016.

\section{Tabel 2. Pengujian Normalitas data} Jurnal Penelitian Ekonomi dan Akuntansi 


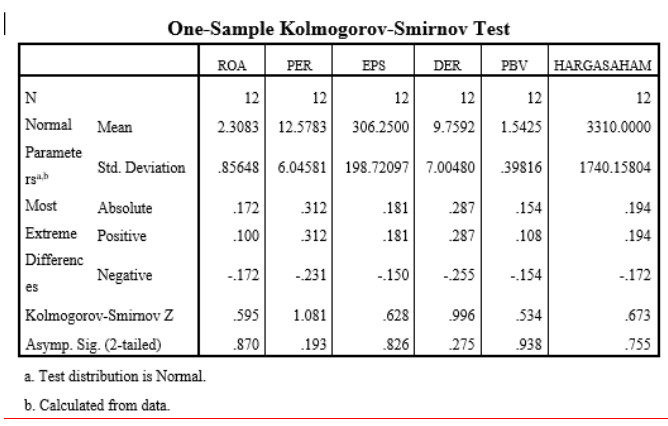

Sumber: Data diolah

Nilai Asymp. Sig. (2-tailed) pada tabel 2 diatas untuk ROA sebesar 0,870, PER sebesar 0,193, EPS sebesar 0,826, DER sebesar 0,275, PBV sebesar 0,938 dan Harga Saham sebesar 0,755. Nilai Asymp. Sig. (2-tailed) dari ke enam variabel tersebut lebih besar dari 0,05 maka distribusi data tersebut dinyatakan normal.

\section{Uji Multikolinearitas}

Pengujian multikolinearitas dilakukan dengan variabel Return on Asset (ROA), Price Earning Ratio (PER), Earning Per Share (EPS), Debt to Equity Ratio (DER), Price to Book Value (PBV), Harga Saham Pada PT.Bank Negara Indonesia (Persero) Tbk. Periode 2005-2016 dapat di lihat dari tabel 3 berikut ini:

Tabel 3. Pengujian Multikolinearitas

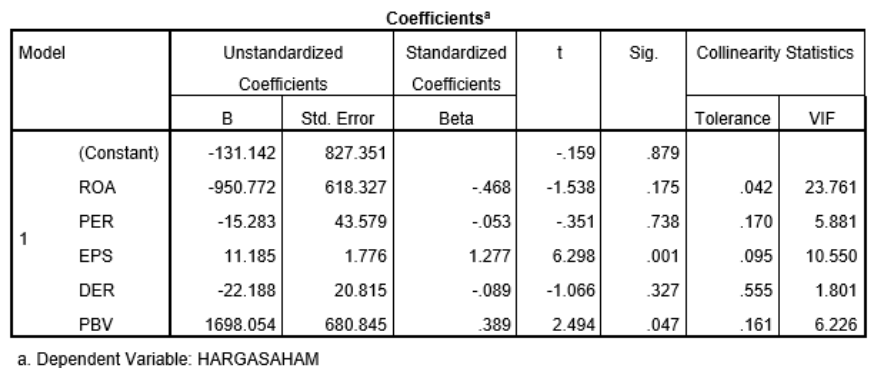

Jurnal Penelitian Ekonomi dan Akuntansi
Sumber: Data diolah

Berdasarkan hasil uji multikolinearitas pada tabel 3 diketahui nilai Tolerance value dari variabel independen ROA sebesar 0,042 $\leq 0,1$ dan EPS sebesar $0.095 \leq 0,1$ serta nilai variance inflation factor (VIF) dari tiap variabel independen ROA sebesar $23.761 \geq 10,00$ dan EPS sebesar 10.550 $\geq 10,00$. Maka dari nilai tersebut dapat diketahui bahwa variabel ROA dan EPS terdapat multikolinearitas, sedangkan Tolerance value dari variabel PER sebesar $0,170 \geq 0.1$, DER sebesar $0,555 \geq 0.1$, PBV sebesar $0,161 \geq 0.1$ dan nilai VIF dari tiap variabel sebesar PER 5,881 $\leq 10,00$, DER sebesar 1,801 $\leq 10,00$, dan PBV sebesar 6,226 $\leq$ 10,00. Dari nilai tersebut dapat disimpulkan bahwa ketiga variabel tersebut tidak terdapat multikolinearitas

\section{Uji Heterokedesitas}

Pengujian heteroskedastisitas dilakukan dengan variabel Return on Asset (ROA), Price Earning Ratio (PER), Earning Per Share (EPS), Debt to Equity Ratio (DER), Price to Book Value (PBV), Harga Saham Pada PT.Bank Negara Indonesia (Persero) Tbk. Periode 2005-2016 dapat di lihat dari gambar 1 berikut ini: 


\section{Gambar 1. Pengujian}

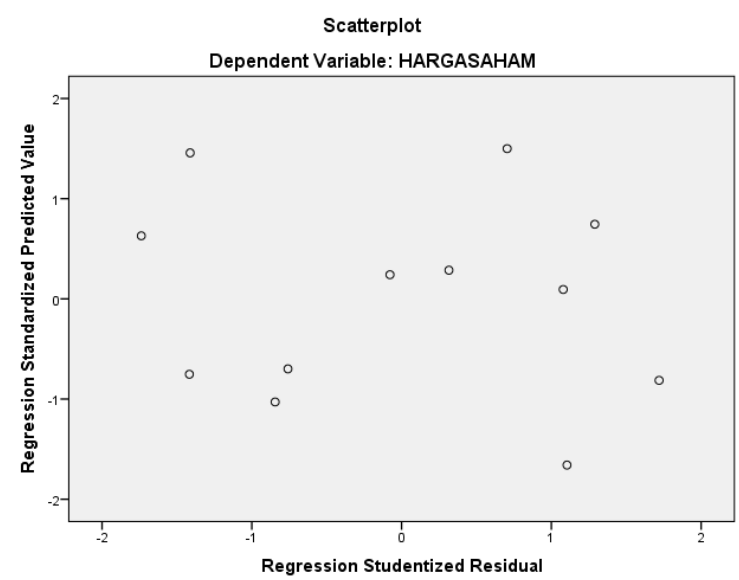

Sumber : Data Diolah

Dari gambar 1 terlihat bahwa titik-titik menyebar secara acak serta bersebar baik di atas maupun di bawah angka 0 pada sumbu Y. Hal ini dapat disimpulkan bahwa tidak terjadi heteroskedastisitas pada model regresi.

\section{Uji Autokorelasi}

Pengujian Autokorelasi dilakukan dengan variabel Return on Asset (ROA), Price Earning Ratio (PER), Earning Per Share (EPS), Debt to Equity Ratio (DER), Price to Book Value (PBV), Harga Saham Pada PT.Bank Negara Indonesia (Persero) Tbk. Periode 20052016 dapat di lihat dari tabel 4 di bawah ini :

\section{Tabel 4. Uji Autokorelasi}

\begin{tabular}{|l|r|r|c|r|r|}
\hline Model & \multicolumn{1}{|c|}{ Model Summary } \\
\hline 1 & R Square & $\begin{array}{c}\text { Adjusted R } \\
\text { Square }\end{array}$ & $\begin{array}{c}\text { Std. Error of the } \\
\text { Estimate }\end{array}$ & Durbin-Watson \\
\hline
\end{tabular}

a. Predictors: (Constant), PBV, EPS, DER, PER, ROA

b. Dependent Variable: HARGASAHAM

Sumber : Data Diolah
Dapat dilihat dari tabel 4 model summary durbin watson berada di antara nilai $\mathrm{d}=1,843>\mathrm{d}_{\mathrm{u}}=1,76881$ maka tidak terdapat autokorelasi positf, maka model ini tidak terdapat autokorelasi.Dalam uji asumsi klasik ini terdapat multikolinearitas untuk variabel ROA dan EPS, akan tetapi hal tersebut tidak mempengaruhi koefisien regresi maka penelitian ini dilanjutkan dengan mengunakan analisis regresi linier berganda.

\section{Uji Hipotesis Secara Parsial}

\section{(Uji t)}

Uji t digunakan untuk mengetahui apakah variabel-variabel independen secara parsial berpengaruh signifikan atau tidak terhadap variabel dependen. Berdasarkan output coefficients, , berikut ini adalah hasilnya:

\section{Tabel 5. Uji Parsial (Uji t)}

\begin{tabular}{|c|c|c|c|c|c|c|}
\hline & \multicolumn{6}{|c|}{ Coefficients $^{a}$} \\
\hline \multirow[t]{2}{*}{ Model } & & \multicolumn{2}{|c|}{ Unstandardized Coefficients } & \multirow{2}{*}{$\begin{array}{l}\text { Standardized } \\
\text { Coefficients } \\
\text { Beta }\end{array}$} & \multirow[t]{2}{*}{$\mathrm{t}$} & \multirow[t]{2}{*}{ Sig. } \\
\hline & & B & Std. Error & & & \\
\hline \multirow{6}{*}{1} & (Constant) & -131.142 & 827.351 & & -.159 & .879 \\
\hline & ROA & -950.772 & 618.327 & -468 & -1.538 & .175 \\
\hline & PER & -15.283 & 43.579 & -.053 & -351 & .738 \\
\hline & EPS & 11.185 & 1.776 & 1.277 & 6.298 & .001 \\
\hline & DER & -22.188 & 20.815 & -.089 & -1.066 & .327 \\
\hline & PBV & 1698.054 & 680.845 & .389 & 2.494 & .047 \\
\hline
\end{tabular}

Sumber : Data Diolah

a. Pengaruh Return On Asset (ROA) terhadap Harga Saham

Berdasarkan data pada Tabel 5 diketahui pengaruh ROA terhadap harga 
saham pada kolom beta baris pertama diperoleh $\left(\beta_{1} \mathrm{X}_{1}\right)^{2}$ x $100 \%\left((-0.468)^{2} \mathrm{x}\right.$ $100 \%)=21,90 \%$, dengan nilai $\mathrm{t}-$ hitung sebesar -1.538 dan tingkat signifikan 0.175. Sedangkan nilai t-tabel untuk $\quad \mathrm{df}=\mathrm{n}-\mathrm{k} \quad(12-6=6)$ dengan tingkat signifikan sebesar $5 \% \quad(0,05)$ adalah sebesar 1.943. Artinya adalah nilai t-hitung lebih kecil dibandingkan dengan nilai t-tabel $(-1.538<1.943)$ dengan tingkat signifikan $0.175>0.05$ berdasarkan ketentuan maka $\mathrm{H}_{0} 1$ diterima dan $\mathrm{H}_{\mathrm{a}} 1$ ditolak yang artinya secara parsial tidak ada pengaruh signifikan Return On Asset (ROA) terhadap harga saham.

b. Pengaruh Price Earning Ratio (PER) terhadap Harga Saham

Berdasarkan data pada Tabel 5 diketahui pengaruh PER terhadap harga saham pada kolom beta baris kedua diperoleh $\left(\beta_{2} \mathrm{X}_{2}\right)^{2}$ x $100 \%\left((-0.053)^{2} \mathrm{x}\right.$ $100 \%)=0,28 \%$, dengan nilai t-hitung sebesar -0.351 dan tingkat signifikan 0.738 sedangkan nilai t-tabel untuk df $=$ $n-k(12-6=6)$ dengan tingkat signifikan sebesar 5\% $(0,05)$ adalah sebesar 1.943 . Artinya adalah t-hitung lebih kecil dibandingkan dengan nilai t-tabel ($0.351<1,943)$ dengan tingkat signifikan $0.738>0.05$ berdasarkan ketentuan maka $\mathrm{H}_{0} 2$ diterima dan $\mathrm{H}_{2} 2$ ditolak yang artinya secara parsial tidak ada pengaruh signifikan Price Earning Ratio (PER) terhadap harga saham.

c. Pengaruh Earning Per Share (EPS) terhadap Harga Saham

Berdasarkan data pada Tabel 5 diketahui pengaruh EPS terhadap harga saham pada kolom beta baris ketiga diperoleh nilai sebesar $\left(\beta_{3} X_{3}\right)^{2}$ x $100 \%$ $\left((1.277)^{2} \times 100 \%\right)=163 \%$, dengan nilai t-hitung sebesar 6.298 dan tingkat signifikan 0.001 sedangkan nilai t-tabel untuk df = n-k (12-6 = 6) dengan tingkat signifikan sebesar 5\% $(0,05)$ adalah sebesar 1.943. Artinya adalah nilai t-hitung lebih besar dibandingkan dengan nilai t-tabel (6.298> 1.943) dengan tingkat signifikan $0.001<0.05$ berdasarkan ketentuan maka $\mathrm{H}_{0} 3$ ditolak dan $\mathrm{H}_{\mathrm{a}} 3$ diterima yang artinya secara parsial ada pengaruh signifikan kearah positif Earning Per Share (EPS) terhadap harga saham.

d. Pengaruh Debt to Equity Ratio (DER) terhadap Harga Saham

Berdasarkan data pada Tabel 5 diketahui pengaruh DER terhadap harga saham pada kolom beta baris keempat diperoleh nilai sebesar $\left(\beta_{4} \mathrm{X}_{4}\right)^{2}$ x $100 \%$ $\left((-0.089)^{2} \times 100 \%=0,79 \%\right.$, dengan nilai t-hitung sebesar -1.066 dan tingkat signifikan 0.327 sedangkan nilai t-tabel 
untuk df $=\mathrm{n}-\mathrm{k}(12-6=6)$ dengan tingkat signifikan sebesar $5 \%(0,05)$ adalah sebesar 1.943. Artinya adalah nilai t-hitung lebih kecil dibandingkan dengan nilai t-tabel $(-1.066<1,943)$ dengan tingkat signifikan $0.327>0.05$ berdasarkan ketentuan maka $\mathrm{H}_{0} 4$ diterima dan $\mathrm{H}_{\mathrm{a}} 4$ ditolak yang artinya secara parsial tidak ada pengaruh signifikan Debt to Equity Ratio (DER) terhadap harga saham.

e. Pengaruh Price to Book Value (PBV) terhadap Harga Saham

Berdasarkan data pada Tabel 5 diketahui pengaruh PBV terhadap harga saham pada kolom beta baris kelima diperoleh nilai sebesar $\left(\beta_{5} \mathrm{X}_{5}\right)^{2}$ x $100 \%$ $\left((0.389)^{2} \times 100 \%\right)=15,13 \%$, dengan nilai t-hitung sebesar 2.494 dan tingkat signifikan 0.047 sedangkan nilai t-tabel untuk df $=n-k(12-6=6)$ dengan tingkat signifikan sebesar $5 \% \quad(0,05)$ adalah sebesar 1.943. Artinya adalah nilai t-hitung lebih besar dibandingkan dengan nilai t-tabel (2.494>1.943) dengan tingkat signifikan $0.047<0.05$ berdasarkan ketentuan maka $\mathrm{H}_{0} 5$ ditolak dan $\mathrm{H}_{\mathrm{a}} 5$ diterima yang artinya secara parsial ada pengaruh signifikan kearah positif Price to Book Value (PBV) terhadap harga saham.

\section{Uji Hipotesis Secara Simultan}

\section{(Uji F)}

Penulis mengunakan tingkat signifikansi $a=5 \%(0,05)$ dimana tingkat keyakinan sebesar $95 \%$ dan tingkat ketidakyakinan sebesar 5\% yang merupakan tingkat keyakinan penulis dalam penelitian.

\section{Tabel 6. Uji Simultan ( Uji F )}

\begin{tabular}{|c|c|c|c|c|c|c|}
\hline \multicolumn{7}{|c|}{ ANOVA $^{a}$} \\
\hline \multicolumn{2}{|c|}{ Model } & Sum of & df & Mean Square & $\mathrm{F}$ & Sig. \\
\hline \multirow{3}{*}{1} & Regression & 32530612.741 & 5 & 6506122.548 & 50.109 & $.000^{b}$ \\
\hline & Residual & 779037.259 & 6 & 129839.543 & & \\
\hline & Total & 33309650.000 & 11 & & & \\
\hline
\end{tabular}

Sumber : Data Diolah

Dari tabel ANOVA diatas diketahui bahwa nilai $F_{\text {hitung }} 50.109$ dan tingkat signifikan 0,000 . Nilai $F$ tabel dengan menggunakan derajat bebas $\mathrm{V}_{1}$ $=5$ dan $V_{2}=6$ adalah sebesar 4.39 dan tingkat signifikan $0,05(\alpha=5 \%)$. Oleh karena $\quad F_{\text {hitung }} 50.109>F_{\text {tabel }}$ 4.39 dan tingkat signifikasi $0,000<0,05$ maka $\mathrm{H}_{0} 6$ ditolak dan $\mathrm{H}_{\mathrm{a}} 6$ diterima, sehingga dapat disimpulkan bahwa secara simultan terdapat pengaruh antara Return On Asset (ROA), Price Earning Ratio (PER), Earning Per Share (EPS), Debt to Equity Ratio (DER) dan Price to Book Value (PBV) terhadap harga saham PT. Bank Negara Indonesia (Persero) Tbk. Periode tahun 2005-2016 
7. Pengaruh Return On Asset (ROA), Price Earing Ratio (PER), Earning Per Share (EPS), Debt To Equiy Ratio (DER) dan Price To Book Value (PBV) terhadap nilai harga saham pada PT. Bank Negara Indonesia (Persero) Tbk

Menurut Bambang S. Soedibjo (2013:206) dalam analisis regresi perlu mengetahui sampai berapa besar persamaan garis yang dibuat cocok atau sesuai dengan data sempel. Atau dengan perkataan lain "berapa besar proporsi variasi total yang dapat di jelaskan oleh persamaan garis tersebut ?." Ukuran untuk mengetahui hal ini dikenal dengan nama koefisien determinasi atau dinotasikan dengan $\mathrm{R}^{2}$ yang diperoleh dari koefisien korelasi antara $\mathrm{x}$ dan $\mathrm{y}$, $\mathrm{R}^{2}$ adalah sebuah ukuran untuk melihat kecocokan garis regresi. Berikut hasil koefisien determinasi:

Tabel 7. Koefisien Determinasi

\begin{tabular}{|l|r|r|r|c|}
\hline Model & R & R Square & $\begin{array}{c}\text { Adjusted R } \\
\text { Square }\end{array}$ & $\begin{array}{c}\text { Std. Error of the } \\
\text { Estimate }\end{array}$ \\
\hline 1 & $.988^{\mathrm{a}}$ & .977 & .957 & 360.33255 \\
\hline
\end{tabular}
a. Predictors: (Constant), PBV, EPS, DER, PER, ROA

Sumber : Data Diolah

Berdasarkan tabel 7 diketahui hasil perhitungan besarnya nilai koefisien determinasi $\left(\mathrm{R}^{2}\right)$ sebesar 0,977 yang berarti variabilitas variabel dependen yaitu harga saham yang dapat dijelaskan oleh variabel independen yaitu ROA, PER, EPS, DER dan PBV sebesar $97,7 \%$. Sedangkan sisanya $2,3 \%$ (100\%-97,7\%) dijelaskan oleh variabel lain yang tidak peneliti masukan ke dalam model regresi.

Adapun dari hasil analisis regresi yang tertera pada tabel 7 tersebut diperoleh persamaan Return On Asset (ROA), Price Earning Ratio (PER), Earning Per Share (EPS), Debt to Equity Ratio (DER) dan Price to Book Value (PBV) terhadap harga saham, sebagai berikut:

$\mathrm{Y}=(-\mathbf{1 3 1 . 1 4 2})+\left(-950.772 \mathrm{x}_{1}\right)+$

$\left(-15.283 x_{2}\right)+11.185 x_{3}+\left(-22.188 x_{4}\right)+$ $1698.054 \times 5$

Berikut penjelasan untuk hasil persamaan regresi tersebut :

1. Konstanta menunjukan angka 131.142 yang berarti jika semua variabel bebas memiliki nilai nol (0) maka nilai variabel terikatnya (harga saham) sebesar -131.142 atau turun Rp 131,142.

2. Koefisien ROA $\left(X_{1}\right)$ sebesar 950.772 dan bertanda negatif, ini menunjukan bahwa setiap penambahan ROA $\left(\mathrm{X}_{1}\right)$ sebesar Rp 1 maka akan menurunkan harga saham sebesar Rp 950,772 . 
3. Koefisien PER $\left(\mathrm{X}_{2}\right)$ sebesar 15.283 dan bertanda negatif, ini menunjukan bahwa setiap penambahan PER $\left(\mathrm{X}_{2}\right)$ sebesar Rp 1 maka akan menurunkan harga saham sebesar Rp 15,283.

4. Koefisien EPS $\left(\mathrm{X}_{3}\right)$ sebesar 11.185 ini menunjukan bahwa setiap penambahan EPS $\left(\mathrm{X}_{3}\right)$ sebesar Rp 1 maka akan meningkatkan harga saham sebesar Rp 11,185.

5. Koefisien DER $\left(\mathrm{X}_{4}\right)$ sebesar 22.188 dan bertanda negatif, ini menunjukan bahwa setiap penambahan DER $\left(\mathrm{X}_{4}\right)$ sebesar Rp 1 maka akan menurunkan harga saham sebesar Rp 22,188.

6. Koefisien PBV (X) sebesar 1698.054 ini menunjukan bahwa setiap penambahan PBV $\left(\mathrm{X}_{5}\right)$ sebesar Rp 1 maka akan meningkatkan harga saham sebesar Rp 1.698.

\section{PENUTUP}

Dari Hasil uji $F$ diperoleh nilai $F_{\text {hitung }}$ sebesar 50.109 dan tingkat signifikan 0,000. Nilai $F$ tabel dengan menggunakan derajat bebas $\mathrm{V}_{1}=5$ dan $\mathrm{V}_{2}=6$ adalah sebesar 4.39 dan tingkat signifikan $0,05(\alpha=5 \%)$. Oleh karena $\mathrm{F}_{\text {hitung }} 50.109>\mathrm{F}_{\text {tabel }} 4.39$ dan tingkat signifikasi $0,000<0,05$ maka $\mathrm{H}_{0} 6$ ditolak dan $\mathrm{H}_{\mathrm{a}} 6$ diterima, sehingga dapat disimpulkan bahwa secara simultan terdapat pengaruh antara
Return On Asset (ROA), Price Earning Ratio (PER), Earning Per Share (EPS), Debt to Equity Ratio (DER) dan Price to Book Value (PBV) terhadap harga saham PT. Bank Negara Indonesia (Persero) Tbk. Periode tahun 2005-2016 sebesar $97,7 \%$. Sedangkan sisanya $2,3 \%$ (100\%-97,7\%) dijelaskan oleh variabel lain yang tidak peneliti masukan ke dalam model regresi.

\section{DAFTAR PUSTAKA}

Agus, Sartono. 2008. Manajemen Keuangan Teori dan Aplikasi Edisi Empat.Yogyakarta: BPFE.

Bambang S. Soedibjo. 2013. Pengantar Metode Penelitian. Bandung : Universitas Nasional PASIM.

Brigham dan Houston. 2010. Dasardasar Manajemen Keuangan Buku 1 (Edisi 11). Jakarta : Salemba Empat.

Darmadji dan Fakhruddin. 2011. Pasar Modal di Indonesia, edisi 3. Jakarta : Salemba Empat. 
Eduardus, Tandelilin. 2010. Portofolio dan Investasi, Edisi Ketujuh. Yogyakarta: Kanisius.

Hartono Jogiyanto . 2008. Teori Portofolio Dan Analisis Investasi. Yogyakarta: BPFE.

Husnan, Suad dan Enny Pudjiastuti. 2006. Dasar-Dasar Manajemen Keuangan. Edisi Kelima. UPP STIM YKPN : Yogyakarta.

Ikatan Akuntan Indonesia. 2015. Standar Akuntansi Keuangan. Jakarta: Dewan Standar Akuntansi Keuangan Ikatan Akuntan Indonesia.

Iman Santoso. 2009. Akuntansi Keuangan Menengah (Intermediate Accounting ), Buku Satu, Refika Aditama : Bandung

Irham, Fahmi. 2013. Analisis Laporan Keuangan. Bandung: Alfabeta.

Kasmir. 2012. Dasar-Dasar Perbankan. Jakarta : Rajawali Pers. - 2013. Bank dan Lembaga Keuangan Lainnya. Jakarta: Rajawali Pers.
Munawir . 2014. Analisis Laporan Keuangan, Edisi 4. Yogyakarta : Liberty.

Sofyan Syafri Harahap.2011. Teori Akuntansi edisi revisi 2011.Jakarta : Rajawali Pers.

Sutrisno. 2012. Manajemen Keuangan Teori, Konsep dan Aplikasi, Edisi Pertama, Cetakan Ketujuh. Yogyakarta : Ekonisia.

Subramanyam. K. R dan John J. Wild. 2014. Analisi Laporan Keuangan. Penerjemah Dewi Y. Jakarta: Salemba Empat.

http://www.bni.co.id/id/perusahaan/hub unganinvestor/laporanpresentasi www.bi.go.id/ 
